\title{
Large-Scale Analysis of High Frequency Electromagnetic Field by Hierarchical Domain Decomposition Method
}

\author{
Amane Takei Member (The University of Tokyo, takei@garlic.q.t.u-tokyo.ac.jp) \\ Shinobu Yoshimura Non-member (The University of Tokyo, yoshi@q.t.u-tokyo.ac.jp) \\ Hiroshi Kanayama Member (Kyushu University, kanayama@mech.kyushu-u.ac.jp)
}

Keywords : high frequency electromagnetic field, Helmholtz equations, finite element method, hierarchical domain decomposition method

This paper describes large-scale analysis for high frequency electromagnetic field by the finite element analysis of Maxwell equations including the displacement current. A stationary Helmholtz equation for the high frequency electromagnetic field analysis is solved taking an electric field $\mathrm{E}$ and an electric scalar potential $\phi$ as unknown functions. Domain decomposition methods enable the acceleration of the solution to large-scale analysis problems. Hierarchical domain decomposition method (HDDM) is employed as a parallel solver based on the iterative domain decomposition method. HDDM has some modes depending on the roles of processors. In this study, the Parent-Only type (Parallel processor mode: P-mode) is employed. In the P-mode, Parent processors perform the finite element analysis (FEA) by themselves. In this mode, since all processors perform the FEA, all CPUs can be used without idleing in an environment with 10-20 CPUs. Figure 1 shows a diagram of the data distribution and communication in the P-mode.

A whole body cavity resonator: Testing Electromagnetic Analysis Method (TEAM) Workshop problem 29 is used as a numerical example to verify the accuracy of our analysis by Mesh(1). Numerical examples demonstrate that the developed method can compute large-scale problems with over 10 million unknowns by Mesh(2),(3). All calculations were performed on a 18 node (36 cores) PC cluster with Core2Duo $1.86 \mathrm{GHz}$ processors and $2 \mathrm{~GB}$ of RAM. Table 1 shows the numbers of elements and degrees of freedom (DOF) for E- $\phi$ Method and

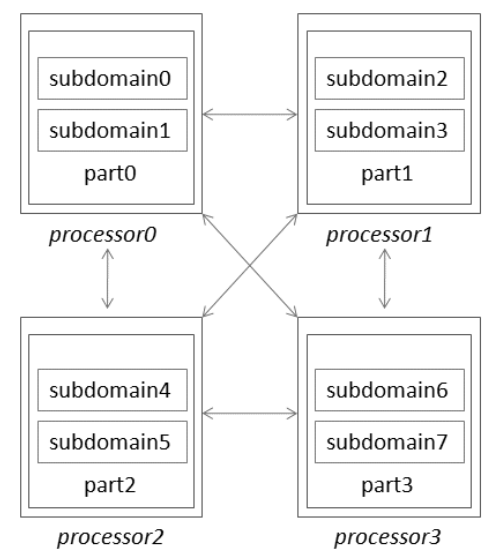

Fig. 1. Data distribution and communication in the parallel processor mode (P-mode) subdomains.

Numerical results are shown in Table 2 and Table 3. As shown by the verification of accuracy, the numerical solutions agree well with the measured data and FDTD solutions. For Mesh(2), by using the E- $\phi$ Method, the CPU solving time is reduced by 11.5 [\%] as compared to the E Method. For Mesh(3), while the E Method did not converge, by the E- $\phi$ Method the result could be successfully computed. Regarding memory usage, although the E$\phi$ Method uses roughly $10[\%]$ more memory, the total amount being used does not exceed 25 [\%] of the available RAM even for Mesh(3). Therefore, we do not consider memory usage to be a problem.

Table 1. Meshes for verifications

\begin{tabular}{|c|c|c|c|}
\hline & Element & DOF & Subdomain \\
\hline $\operatorname{Mesh}(1)$ & 108,787 & 134,889 & $36 \times 302$ \\
\hline $\operatorname{Mesh}(2)$ & $4,528,311$ & $6,108,779$ & $36 \times 1,258$ \\
\hline $\operatorname{Mesh}(3)$ & $10,073,267$ & $13,515,847$ & $36 \times 2,798$ \\
\hline
\end{tabular}

Table 2. Comparison of resonant frequencies in $\mathrm{MHz}$

\begin{tabular}{|c|c|c|c|c|}
\hline $\begin{array}{c}\text { Resonance } \\
\text { mode }\end{array}$ & Measured $^{(12)}$ & $\begin{array}{c}\text { FDTD }^{(12)} \\
25 \mathrm{~mm} \\
\text { mesh }\end{array}$ & $\begin{array}{c}\text { Result } \\
: \mathrm{E}\end{array}$ & $\begin{array}{c}\text { Result } \\
: \mathrm{E}-\phi\end{array}$ \\
\hline 1st & 68.6 & $\begin{array}{c}67 \\
(2.33)\end{array}$ & $\begin{array}{c}65.2 \\
(4.96)\end{array}$ & $\begin{array}{c}65.2 \\
(4.96)\end{array}$ \\
\hline 2nd & 110 & 110 & $\begin{array}{c}109 \\
(0.91)\end{array}$ & $\begin{array}{c}109 \\
(0.91)\end{array}$ \\
\hline 3rd & 134 & 134 & 134 & 134 \\
\hline \multicolumn{2}{|c|}{ ( ): Error rate between measured data and numerical solutions [\%] }
\end{tabular}

Table 3. CPU time and memory requirements for each mesh

\begin{tabular}{|c|c|c|c|c|}
\hline \multirow{2}{*}{$\operatorname{Mesh}(2)$} & $\begin{array}{c}\text { Formula } \\
\text {-tion }\end{array}$ & Unknowns & $\begin{array}{c}\text { CPU } \\
\text { time [h] }\end{array}$ & $\begin{array}{c}\text { Memory } \\
\text { size } \\
\text { [M Byte] }\end{array}$ \\
\cline { 2 - 5 } & E- $\phi$ & $6,108,799$ & 6.44 & 2,100 \\
\hline \multirow{2}{*}{$\operatorname{Mesh}(3)$} & E & $11,857,646$ & - & - \\
\cline { 2 - 5 } & E- $\phi$ & $13,515,847$ & 16.77 & 8,244 \\
\hline
\end{tabular}




\section{階層型領域分割法による高周波電磁場の大規模解析

$\begin{array}{llll}\text { 正武居 } & \text { 周* } \quad \text { 非会員 吉村 忍* } \\ \text { 正 員 金山 } & \text { 寛** } & & \end{array}$ \\ Large-Scale Analysis of High Frequency Electromagnetic Field by Hierarchical Domain Decomposition Method}

Amane Takei*, Member, Shinobu Yoshimura*, Non-member, Hiroshi Kanayama**, Member

This paper describes large-scale analysis for high frequency electromagnetic field by the finite element analysis of Maxwell equations including the displacement current. A stationary Helmholtz equation for the high frequency electromagnetic field analysis is solved taking an electric field and an electric scalar potential as unknown functions. Domain decomposition methods enable the acceleration of the solution to large-scale analysis problems. Hierarchical domain decomposition method (HDDM) is employed as a parallel solver based on the iterative domain decomposition method. A whole body cavity resonator: TEAM Workshop problem 29 is used as a numerical example to verify the accuracy of our analysis. Numerical examples demonstrate that the developed method can compute large-scale problems over 10 million unknowns.

キーワード : 高周波電磁場, Helmholtz 方程式, 有限要素法, 階層型領域分割法

Keywords : high frequency electromagnetic field, Helmholtz equations, finite element method, hierarchical domain decomposition method

\section{1. まえがき}

EMI (Electro-Magnetic Immunity) を考慮した電気電子機器 設計や電磁環境解析問題等において, 高周波電磁場解析手 法の研究・開発が要求されている。

現在，高周波電磁場解析においては，理論体系が明快で あり, かつ Yee 格子内で電磁波伝播の物理的描象を表現し ていることから直感的にシミュレーションを行うことが可 能な FDTD (Finite difference time domain) 法がしばしば用い られている(1)。しかしながら, 複雑な計算モデルの作成を行 った場合，部分的に微細構造となることから FDTD 法で用 いられているような直方格子によるメッシュ分割では，計 算規模が極端に大きくなる可能性がある(2)。したがって，非 構造格子により境界適合性が確保される有限要素法がより 望ましいと考えられる。

高周波問題において解くべき方程式となる Helmholtz 方 程式を有限要素法によって定式化した場合，熱伝導解析の

\footnotetext{
* 東京大学大学院工学系研究科システム量子工学専攻

T113-8656 東京都文京区本郷 7-3-1

Department of Quantum Engineering and Systems Science,

The University of Tokyo

7-3-1, Bunkyo-ku, Tokyo 113-8656

** 九州大学大学院工学研究院機械工学部門

干819-0395 福岡市西区元岡 744

Department of Mechanical Engineering, Faculty of Engineering, Kyushu University

744, Motooka, Nishi-ku, Fukuoka 819-0395
}

場合などと比較して ICCOCG (Incomplete Cholesky Conjugate Orthogonal Conjugate Gradient) 法の収束特性が好ましくな いことが知られている(3)。近年, 解くべき問題の大規模化に よって有限要素解析において大規模な連立一次方程式を解 くことが必要とされるが, 連立一次方程式の規模が大きく なるにしたがい, ICCOCG 法の収束特性が悪化する傾向が 顕著となる ${ }^{(5)}$ 。また, PARDISO ${ }^{(4)}$ をはじめとする直接法ソル バーは Matrix を記憶する際に多くのメモリ量を要するた め, 計算可能な自由度は 20～30 万が上限となる。そのため, 数百万〜数千万自由度規模の解析では, 直接法と比較して 使用メモリ量が少ない反復法を適用する必要がある。

したがって，計算規模の増大に対してロバストな反復法 および並列化手法の検討が必要となるが, 複雑な領域の解 析が必要となる電磁環境問題など大規模問題への適用はい まだ困難な状況にある ${ }^{(6) \sim(8)}$ 。文献( 7 )において 370 万自由度 の実環境モデルによる解析について報告されているが， 500 万自由度以上, 特に 1,000 万自由度規模の解析に関寸る報告 は殆よ゙ない。

筆者らは, 領域分割型の並列化手法を適用する数 $\mathrm{MHz} \sim$ 数 $\mathrm{GHz}$ の高周波電磁場の数百万〜数千万自由度規模の大規 模有限要素解析手法に関して検討している。本手法は解析 領域を重なりを持たないいくつかの領域に分割することに よって, 解くべき有限要素方程式をインターフェース問 題 ${ }^{(9)(10)}$ に帰着させる。インターフェース問題の解法には反復 
型領域分割法(11)を適用し，階層型領域分割法(Hierarchical Domain Decomposition Method : HDDM) $)^{(12) \sim(14)}$ によって並列 計算機環境上へ実装した。階層型領域分割法は大規模問題 を効率よく実装するための手法であり，これまでに約一億 自由度の静弾性解析や数千万自由度の熱伝導解析および低 周波渦電流解析等を実現しており，本研究においてもその 効果が期待できる。

本研究では, 有限要素法の定式化において, 電場 $\mathrm{E}$ を未 知関数とする $\mathrm{E}$ 法, 電場 $\mathrm{E}$ およびスカラーポテンシャル $\phi$ を未知関数とする E- $\phi$ 法についてそれぞれ定式化し，その インターフェース問題に対して COCG (Conjugate Orthgonal Conjugate Gradient) 法に基づく反復型領域分割法を適用し た。低周波渦電流問題において，ベクトルポテンシャル $\mathbf{A}$ を未知数とした A 法に対してスカラーポテンシャル $\phi$ を末 知数として導入した A- $\phi$ 法によってインターフェース問題 の計算時間が短縮されることが示されているが，本問題に おいても同様の効果が得られることを確認する(14)。手法の 検証として数值電磁場解析の標準問題の 1 つである TEAM (Testing Electromagnetic Analysis Methods) Workshop Problem 29 に基づくリエントラント型空洞共振器モデル(15)(16)を用い て, 精度検証および性能検証を行う。精度検証において, 計算值と実測值および FDTD 法による計算值との比較によ って, 手法の妥当性を検討する。また, E- $\phi$ 法におけるスカ ラーポテンシャル $\phi$ 導入による計算時間の短縮効果や使 用メモリサイズに与える影響などを吟味する。性能検証は 精度検証用モデルのメッシュ分割数を変更した大規模モデ ルによって 600 万および 1,200 万複素自由度規模の計算を行 う。これまでに高周波電磁場問題において, スカラーポテ ンシャル $\phi$ を考慮した定式化の優位性を 500 万〜 1,000 万自 由度規模の解析において具体的に示した報告はない。性能 検証において，E 法および E- $\phi$ 法のインターフェース問題 の収束特性や使用メモリ量などを比較検討することによっ て，本手法の大規模問題に対する有効性を示す。

\section{2. 有限要素定式化}

〈2·1〉 $E$ 法による定式化 領域 $\Omega$ を考え, その境界 を $\partial \Omega$ とする。変位電流を含む Maxwell 方程式より導かれる 電場 $\mathbf{E}[\mathrm{V} / \mathrm{m}]$ を未知関数とした Helmholtz 方程式(1)を考え $ろ^{(5)(17)(18)}$ 。

$$
\begin{aligned}
& \operatorname{rot}\left(1 / \mu_{r} \operatorname{rot} \mathbf{E}\right)-k_{0}^{2} \varepsilon_{r} \mathbf{E}=j \omega \mu_{0} \mathbf{J} \quad \text { in } \Omega \\
& \mathbf{E} \times \mathbf{n}=\mathbf{0} \quad \text { on } \partial \Omega \\
& \mathbf{J}=\sigma \hat{\mathbf{E}}
\end{aligned}
$$

電場 $\mathbf{E}$ は単一角周波数 $\omega[\mathrm{rad} / \mathrm{s}]$ をつ。 $k_{0}{ }^{2}=\omega^{2} \mu_{0} \varepsilon_{0}$ であり， $\varepsilon_{0}$ は真空の誘電率 $[\mathrm{F} / \mathrm{m}], \mu_{0}$ は真空の透磁率 $[\mathrm{H} / \mathrm{m}]$ である。 $\varepsilon_{r}$ は媒質に依存する比誘電率, $\mu_{r}$ は比透磁率であり共に無次元 量である。誘電率は $\varepsilon=\varepsilon_{0} \varepsilon_{r}$, 透磁率は $\mu=\mu_{0} \mu_{r}$ で与えられる。 $j$ は虚数単位を表し, $\mathbf{n}$ は境界での外向き単位法線ベクトル である。また， $\hat{\mathbf{E}}$ は既知の電場を表す。本定式化において 誘電率は複素誘電率 $\varepsilon=\varepsilon_{0} \varepsilon_{r}=\varepsilon_{0} \varepsilon_{r}{ }^{\prime}+\sigma / j \omega$ となる。 $\sigma$ は導電率
$[\mathrm{S} / \mathrm{m}]$ である。

本解析手法では, 電場強度, 磁場強度および電磁場のエ ネルギー密度に相当する Poynting vector が計算される。解く べき方程式は(1a)式であり, 複素誘電率 $\varepsilon$, 透磁率 $\mu$ および 角周波数 $\omega$ を既知として, Ohm の法則に基づく構成式(1c) によって電流密度 $\mathbf{J}\left[\mathrm{A} / \mathrm{m}^{2}\right]$ と関連付けられる既知節点值 $\hat{\mathbf{E}}$ を与え，(1b)式で与えられる基本境界条件を課した上で有限 要素解析により未知関数である電場 $\mathbf{E}$ を計算する。一方, 得られた電場 $\mathbf{E} よ り$ Maxwell 方程式のひとつである(2)式を 用いた後処理によって要素ごとに磁場 $\mathbf{H}[\mathrm{A} / \mathrm{m}]$ を計算する。 さらに，(3)式によって Poynting vector の時間平均值 $<\mathbf{S}>\left[\mathrm{W} / \mathrm{m}^{2}\right]$ を計算する ${ }^{(17)(20)}$

$$
\begin{aligned}
& \operatorname{rot} \mathbf{E}-j \omega \mu_{0} \mu_{r} \mathbf{H}=\mathbf{0} \\
& <\mathbf{S}>=\operatorname{Re}\left[\frac{1}{2} \mathbf{E} \times \overline{\mathbf{H}}\right]
\end{aligned}
$$

$\operatorname{Re}[$ ・ ] ・の実数部を示し,$\overline{\mathbf{H}}$ は $\mathbf{H}$ の複素共役をとるこ とを意味する。

ここで, 領域 $\Omega$ の有限要素分割を考える。未知関数であ る電場 E を Nedelec 四面体一次要素（辺要素） (19)で近似す る。( . . . ) 領域 $\Omega$ 上の $L^{2}$ 内積, $\mathbf{E}_{\mathbf{h}}, \mathbf{J}_{\mathbf{h}}$ はそれぞれ $\mathbf{E}, \mathbf{J}$ の 有限要素近似とし, $\mathbf{E}_{\mathbf{h}}{ }^{*}$ は $\partial \Omega$ 上で $\mathbf{E}_{\mathbf{h}}{ }^{*} \times \mathbf{n}=\mathbf{0}$ となる任意の試 験関数とする。このとき, (1)式に対して有限要素近似を行 うと，有限要素方程式は(4)式のようになる。

$$
\left(1 / \mu_{r} \operatorname{rot} \mathbf{E}_{\mathbf{h}}, \operatorname{rot} \mathbf{E}_{\mathbf{h}}^{*}\right)-\left(k_{0}{ }^{2} \varepsilon_{r} \mathbf{E}_{\mathbf{h}}, \mathbf{E}_{\mathbf{h}}{ }^{*}\right)-\left(j \omega \mu_{0} \mathbf{J}_{\mathbf{h}}, \mathbf{E}_{\mathbf{h}}^{*}\right)=0
$$

〈2·2〉 E- $\phi$ 法による定式化 ここで, 前節で述べた E 法に対して新たに未知関数としてスカラーポテンシャル $\phi$ を導入する。まず, 電場 $\mathbf{E} を(5)$ 式に示す Helmholtz の定理 によって回転成分 $\mathbf{E}_{1}$ と発散成分 $\mathbf{E}_{2}$ に分解する。

$$
\begin{aligned}
& \mathbf{E}=\mathbf{E}_{1}+\mathbf{E}_{2} \\
& \operatorname{div} \mathbf{E}_{1}=0 \\
& \operatorname{rot} \mathbf{E}_{2}=\mathbf{0} \cdots \cdots \\
& \mathbf{E}_{2}=-\operatorname{grad} \varphi
\end{aligned}
$$

(5)式を(1a)式に代入し， $\mathbf{E}_{1}$ を $\mathbf{E}$ とあらためると(6a)式が 得られる。

$$
\begin{aligned}
& \operatorname{rot}\left(1 / \mu_{r} \operatorname{rot} \mathbf{E}\right)-k_{0}{ }^{2} \varepsilon_{r}(\mathbf{E}-\operatorname{grad} \varphi) \\
& =j \omega \mu_{0} \mathbf{J} \quad \text { in } \Omega \text {......... } \\
& \operatorname{div}\left\{k_{0}{ }^{2} \varepsilon_{r}(\mathbf{E}-\operatorname{grad} \varphi)\right\}=0 \quad \text { in } \Omega \\
& \mathbf{E} \times \mathbf{n}=\mathbf{0}, \quad \varphi=0 \quad \text { on } \partial \Omega \\
& \mathbf{J}=\sigma \hat{\mathbf{E}}
\end{aligned}
$$

(6b)式は(6a)式の両辺の発散を取ることによって得られ る。ここで, (6a), (6b)式を連立して解くことを考え, E 法と 同様に複素誘電率 $\varepsilon$, 透磁率 $\mu$ および角周波数 $\omega$ を既知とし て構成(6d)式によって既知節点值 $\hat{\mathbf{E}}$ 与え, (6c)式で与えら 
れる基本境界条件を課した上で有限要素解析により未知関 数である電場 $\mathbf{E}$ およびスカラーポテンシャル $\phi$ を計算する。 (6d)式は(6a)式の電流密度 $\mathbf{J}$ の回転成分のみに寄与し，発散 成分は電流密度 $\mathbf{J}$ を電磁場源として直接用いる場合に考慮 される。 $\phi_{h}$ を $\phi$ の四面体一次要素による有限要素近似とし, $\phi_{h}{ }^{*}$ を $\partial \Omega$ 上で $\phi_{h}{ }^{*}=0$ となる任意の試験関数として, (6)式に 対して有限要素近似を行うと, 有限要素方程式は( 7 )式のよ うになる。

$$
\begin{aligned}
& \left(1 / \mu_{r} \operatorname{rot} \mathbf{E}_{\mathbf{h}}, \operatorname{rot} \mathbf{E}_{\mathbf{h}}^{*}\right)-k_{0}{ }^{2} \varepsilon_{r}\left(\mathbf{E}_{\mathbf{h}}, \mathbf{E}_{\mathbf{h}}^{*}\right) \\
& \quad+k_{0}{ }^{2} \varepsilon_{r}\left(\operatorname{grad} \varphi_{h}, \mathbf{E}_{\mathbf{h}}{ }^{*}\right)-\left(j \omega \mu_{0} \mathbf{J}_{\mathbf{h}}, \mathbf{E}_{\mathbf{h}}^{*}\right)=0
\end{aligned}
$$

$$
k_{0}^{2} \varepsilon_{r}\left(\mathbf{E}_{\mathbf{h}}, \operatorname{grad} \varphi_{h}^{*}\right)-k_{0}^{2} \varepsilon_{r}\left(\operatorname{grad} \varphi_{h}, \operatorname{grad} \varphi_{h}^{*}\right)=0
$$

E 法, E- $\phi$ 法による定式化は，高周波電磁場解析において 無視できない変位電流が含まれる Maxwell の方程式に基づ くものであり, 低周波渦電流解析の定式化では考慮されて いなかった電場 $\mathbf{E}$ が計算される。また，有限要素解析によ って得られた電場 $\mathbf{E}$ を数值処理することによって磁場 $\mathbf{H}$ お よび Poynting vector の時間平均值 $<\mathbf{S}>$ が計算される。

\section{3. 並列計算アルゴリズム}

〈3.1〉 インターフェース問題 大規模連立一次方程 式を効率よく計算するために, 領域分割法に基づく並列化 アルゴリズムを導入する。前章で示した解くべき有限要素 方程式(4)および( 7 )式を( 8 )式のように書き換える。

$$
K u=f
$$

ここで， $K$ は係数行列であり, 複素対称行列である。また $u$ は未知ベクトル, $f$ は既知ベクトルである。要素を最小単 位として，領域 $\Omega$ を領域間境界に重なりを持たないように $\mathrm{N}$ 個に分割する。

$$
\Omega=\bigcup_{i=1}^{N} \Omega^{(i)}
$$

添え字 $(i)$ は部分領域番号であり, 以下，添え字 $(i)$ は $\Omega^{(i)}$ に 関するデータであることを表す。このとき新たに生じる領 域間境界上の自由度を $u_{B}$ とし，部分領域内部節点に関する 自由度を $u_{I}^{(i)}$ として領域分割すると(8)式は(10)式のように 示される。

$$
\begin{gathered}
{\left[\begin{array}{cccc}
K_{I I}^{(1)} & \cdots & 0 & K_{I B}^{(1)} R_{B}^{(1) T} \\
0 & \ddots & \vdots & \vdots \\
0 & \cdots & K_{I I}^{(N)} & K_{I B}^{(N)} R_{B}^{(N) T} \\
R_{B}^{(1)} K_{I B}^{(1) T} & \cdots & R_{B}^{(N)} K_{I B}^{(N) T} & \sum_{i=1}^{N} R_{B}^{(i)} K_{B B}^{(i)} R_{B}^{(i) T}
\end{array}\right]\left[\begin{array}{c}
u_{I}^{(1)} \\
\vdots \\
u_{I}^{(N)} \\
u_{B}
\end{array}\right]} \\
=\left[\begin{array}{c}
f_{I}^{(1)} \\
\vdots \\
f_{I}^{(N)} \\
f_{B}
\end{array}\right] \cdots \cdots \cdots \cdots \cdots \cdots \cdots \cdots \cdots \cdots \cdots \cdots \cdots \cdots \cdots \cdots \cdots \cdots \cdots \cdots \cdots \cdots \cdots \cdots
\end{gathered}
$$

ここに, $R_{B}^{(i)^{T}}$ は $u_{B}$ を部分領域 $\Omega^{(i)}$ の内部自由度 $u_{B}^{(i)}$ 一制限
する 0-1 行列である。これより(11)式および(12)式が得られ る。

$$
\begin{array}{r}
K_{I I}^{(i)} u_{I}^{(i)}=f_{I}^{(i)}-K_{I B}^{(i)} u_{B}^{(i)}, \quad i=1, \ldots, N \ldots \ldots \ldots . . \\
\left\{\sum_{i=1}^{N} R_{B}^{(i)}\left\{K_{B B}^{(i)}-K_{I B}^{(i) T}\left(K_{I I}^{(i)}\right)^{-1} K_{I B}^{(i)}\right\} R_{B}^{(i) T}\right\} u_{B} \\
=\sum_{i=1}^{N} R_{B}^{(i)}\left\{f_{B}^{(i)}-K_{I B}^{(i) T}\left(K_{I I}^{(i)}\right)^{-1} f_{I}^{(i)}\right\} \ldots \ldots
\end{array}
$$

ここに， $f_{B}^{(i)}$ は $u_{B}$ に関する方程式の右辺ベクトルである。 (12)式はインターフェース問題 ${ }^{(9)(10)}$ と呼ばれ, 領域分割法に おいて領域間の連続性を満たすための式である。また $\left(K_{I I}^{(i)}\right)^{-1}$ は $K_{I I}^{(i)}$ の逆行列である。次に, (12)式を(13)式のように書き 換える。

$$
\mathrm{Su}_{B}=\mathrm{g}
$$

ただし

$$
\begin{aligned}
& S=\sum_{i=1}^{N} R_{B}^{(i)} S^{(i)} R_{B}^{(i) T} \ldots \ldots \ldots \ldots \ldots \ldots \ldots \ldots \ldots \\
& S^{(i)}=K_{B B}^{(i)}-K_{I B}^{(i) T}\left(K_{I I}^{(i)}\right)^{-1} K_{I B}^{(i)}
\end{aligned}
$$

である。ここで $S$ は，シュアコンプリメント行列， $S^{(i)}$ は部 分領域 $\Omega^{(i)}$ におけるローカルシュアコンプリメント行列で ある。また $g$ は(12)式における右辺べクトルである。

〈3·2〉 反復型領域分割法 (13)式に示すインターフ ェース問題に対して, COCG 法に基づくアルゴリズムを適 用し，最初に内部境界自由度 $u_{B}$ を計算する。ただし， $\delta$ は 収束判定值で非負の定数である。

ここで\|・川は MAXノルムを表す。初期残差計算時(a)およ び各 COCG ステップの(b)においてシュアコンプリメント行 列 $S$ のベクトル積演算を行う必要があるが, $S$ の構築は係数 行列 $K$ と比較して膨大な計算が必要となる。そこで, 実際 には(14)式を利用することでアルゴリズム中の(a), (b)を以下 のように置き換えて $S$ を陽に作成することなく計算す $ろ^{(11)(14)}$ 。

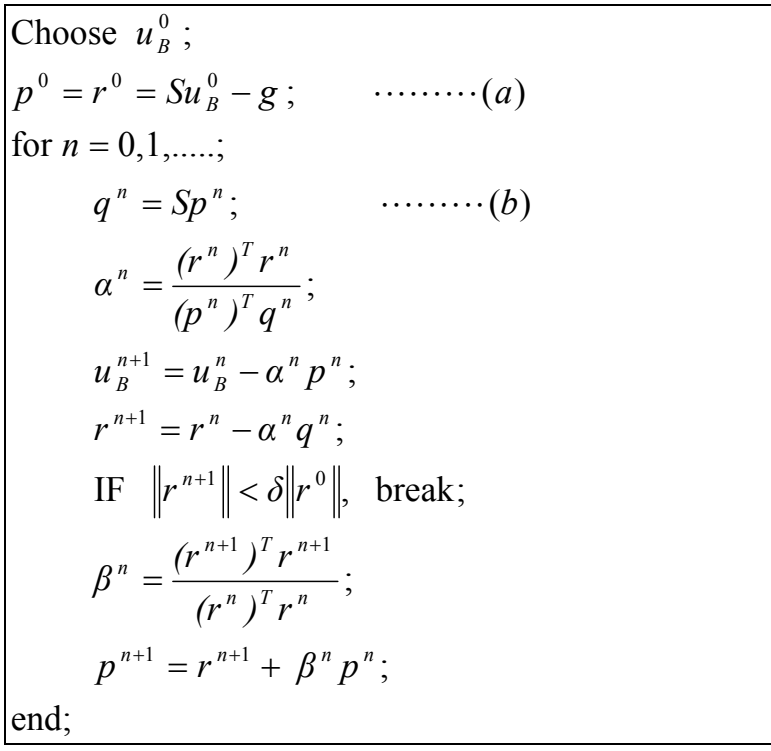




\begin{tabular}{|c|} 
(a) $\quad \begin{array}{c}\text { In each subdomain } \\
\text { Compute } u_{I}^{(i) 0} \text { by } \\
K_{I I}^{(i)} u_{I}^{(i) 0}=f_{I}^{(i)}-K_{I B}^{(i)} R_{B}^{(i)^{T}} u_{B}^{0} ; \\
r^{(i) 0}=K_{I B}^{(i) T} u_{I}^{(i) 0}+K_{B B}^{(i)} R_{B}^{(i)^{T}} u_{B}^{0}-f_{B}^{(i)} ; \\
p^{0}=r^{0}=\sum_{i=1}^{N} R_{B}^{(i)} r^{(i) 0} ; \\
\text { In each subdomaiin } \\
\text { Compute } p_{I}^{(i) n} \text { by } \\
K_{I I}^{(i)} p_{I}^{(i) n}=-K_{I B}^{(i)} R_{B}^{(i)^{T}} p^{n} ; \\
q^{(i) n}=K_{I B}^{(i)} p_{I}^{(i) n}+K_{B B}^{(i)} R_{B}^{(i) T^{T}} p^{n} ; \\
q^{n}=\sum_{i=1}^{N} R_{B}^{(i)} q^{(i) n} ;\end{array}$ \\
\end{tabular}

最後に, (11)式より各部分領域自由度 $u_{I}^{(i)}$ を計算すること で全体領域の解を得ることができる。ここで(a), (b)および (11)式の有限要素計算は部分領域ごとに独立して並列計算 することができる。ここでは，この有限要素計算における 連立一次方程式の解法として ICCOCG 法を適用している。

\section{4. 階層型領域分割法による並列化}

階層型領域分割法 ${ }^{(12) \sim(14)}$ は, 前章で述べた反復型領域分割 法を並列計算機環境へ実装する手法の一つである。階層型 領域分割法は，最初に全体領域を複数のパート (part) に分 割し, さらに各パートをいくつかの部分領域 (subdomain) に分割する 2 段階の階層を持った領域分割である。パート 単位のデータは同個数の Parent と呼ばれるプロセッサに分 配され，メモリ上に記憶する。Parent の数を増やせば大規模 な問題に対応可能となる。階層型領域分割法にはプロセッ サの役割分担などの違いによっていくつかの種類がある。3 世代型(Hierarchical processor mode (3): H-mode(3)) ${ }^{(12)(13)}$ は Grand Parent プロセッサ 1 個が通信制御を行い, Child プロ セッサにおいて部分領域ごとの有限要素計算を, Parent プロ セッサにおいて part のデータ保持やそのほかのベクトル演 算を行う。3 世代型は Child の負荷を動的に分散させること が可能でありプロセッサの性能が不均一な環境では有利と なる半面, Parent-Child 間の通信量が多いことなどから PC クラスタなど均一な環境では効率的ではない。また, 3 世代 型から Grand Parentを省略した親子型 (Hierarchical processor mode : H-mode)も 3 世代型と同様に Parent-Child 間の通信量 が多い欠点をもつ。一方, 親だけ型 (Parallel processor mode: P-mode $)^{(14)}$ は, part 数とプロセッサ数を同数とする。すなわ ち, 全てのプロセッサを Parent として, part のデータ保持や インターフェース自由度の計算等に加えて各部分領域の計 算もまかなうことによって，プロセッサ間の通信を大幅に 削減したものである。図 1 に親だけ型におけるデータの分 配および通信の概念を示す。3 世代型および親子型では Parent は part データの保持, 部分領域データの送受信, イン ターフェース問題における反復計算の処理が主な役割であ

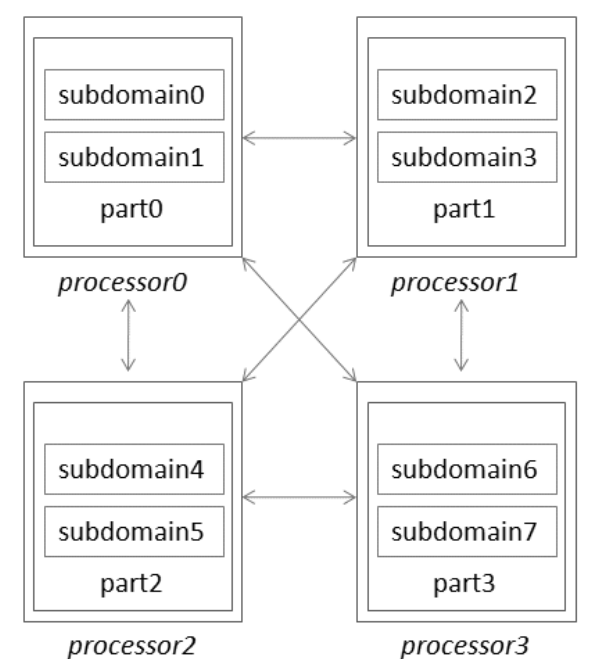

図 1 親だけ型におけるデータの分配および通信

Fig. 1. Data distribution and communication in the parallel processor mode.

るためアイドリング時間が多いが, 親だけ型はこれらに加 えて部分領域計算も行うためプロセッサを無駄なく利用で きる。また, 親だけ型は完全な静的負荷分散であるが, PC クラスタなどでは 3 世代型と比較して通信時間の短縮やプ ロセッサの効率よい利用ができることから, 本研究では親 だけ型を適用した。

\section{5. 手法の検証}

〈5·1〉リエントラント型空洞共振器の解析 ここで はリエントラント型空洞共振器を用いた精度検証に関して 述べる。共振器は直径 $1.9[\mathrm{~m}]$, 高さ $1.45[\mathrm{~m}]$ の円筒型である。 解析では比誘電率 $\varepsilon_{r}=80$, 導電率 $\sigma=0.52[\mathrm{~S} / \mathrm{m}]$ を持った円盤 状の誘電体ファントムを置き共振状態を調べる。電磁場源 は下面に設置されたアンテナである。本問題は TEAM Workshop Problem29 として設定されている標準問題であ る ${ }^{(15)(16)}$ 。困 2(a)に解析モデルの概略および寸法 $[\mathrm{m}]$ を示す。 また, Nedelec 四面体一次要素によって分割したメッシュを 図 2(b)に示す。本節で述べる検証は表 1 に示す 3 種類の検証 用メッシュによって行う。Element は領域内の四面体要素 数, DOF は四面体要素の頂点・辺上に配置された複素自由 度数の合計（E- $\phi$ 法における未知数）を示す。また, Subdomain は部分領域数を示す。部分領域数は, 文献(14)な どで既に報告されている低周波渦電流問題の場合と同様 に, 部分領域 1 つたりに含まれる要素数がおよそ 100 の 場合に最も高い計算性能が得られることから, 1 つの部分領 域に含まれる要素数が 100 となるように決定した。また, 部分領域計算の収束判定值を $10^{-9}$ とし, インターフェース 問題の収束判定值を $10^{-6}$ とした。

〈5·2〉 周波数応答解析による精度検証 Mesh(1)を用 いて精度検証を行った。ここでは共振周波数を検出し, 実 測值と比較検討するために, ある程度の幅の周波数につい て共振状態を調べる。60M[Hz]〜 140M[Hz]を $2 \mathrm{M}[\mathrm{Hz}]$ 刻み, 


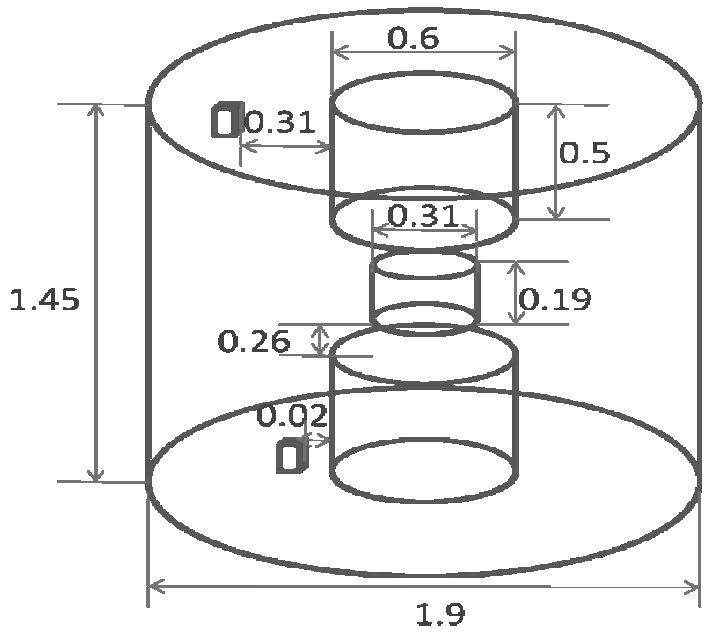

(a) Sketch of the model

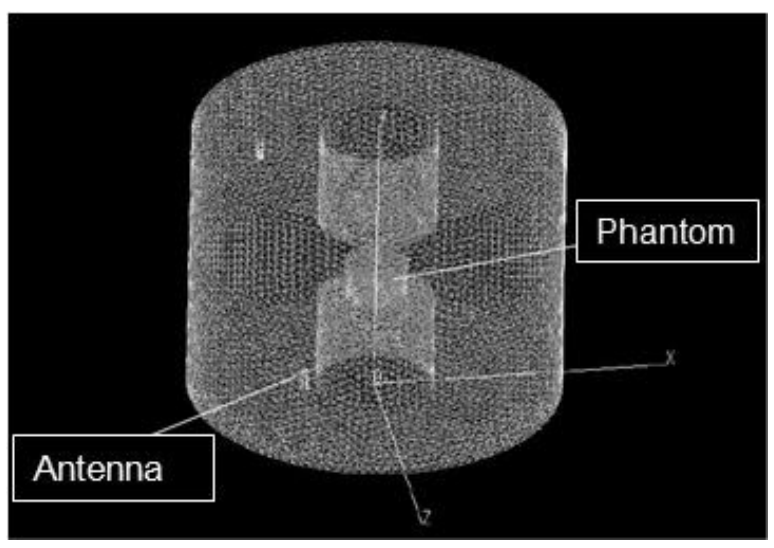

(b) Mesh

図 2 TEAM Workshop Problem29

Fig. 2. TEAM Workshop Problem29.

表 1 検証用メッシュ

Table 1. Meshes for verifications.

\begin{tabular}{|c|c|c|c|}
\hline & Element & DOF & Subdomain \\
\hline $\operatorname{Mesh}(1)$ & 108,787 & 134,889 & $36 \times 302$ \\
\hline $\operatorname{Mesh}(2)$ & $4,528,311$ & $6,108,779$ & $36 \times 1,258$ \\
\hline $\operatorname{Mesh}(3)$ & $10,073,267$ & $13,515,847$ & $36 \times 2,798$ \\
\hline
\end{tabular}

共振周波数付近では $0.4 \mathrm{M}[\mathrm{Hz}]$ 刻みで計算し, 周波数ごとの 応答を調べた ${ }^{(16)(20)}$ 。各ノードに Intel Core2Duo $1.86 \mathrm{GHz}$ のデ ユアルコア $\mathrm{CPU}$ および $2 \mathrm{~GB}$ のメモリが搭載されている $\mathrm{PC}$ クラスタを 18 台 (36 Processor element) 用いて計算した。表 2 に 1 周波数 step あたりの平均計算時間および平均使用メモ リサイズを示す。E 法では 1step あたりの平均計算時間は $0.21[\mathrm{~h}]$ であり，全 $73 \mathrm{step}$ の計算時間は $14.6[\mathrm{~h}]$ であった。ま た E- $\phi$ 法では, 1step あたりの平均計算時間は $0.18[\mathrm{~h}]$ であり, 全 73step の計算時間は 13.4[h]であった。本検証において E$\phi$ 法では, E 法と比較して 1.14 倍高速に計算されており, 低周波渦電流解析問題における A- $\phi$ 法と同様に, スカラー
表 2 計算時間および使用メモリサイズの平均

Table 2. Average of CPU time and memory requirements.

\begin{tabular}{|c|c|c|c|c|}
\hline & $\begin{array}{c}\text { Formu } \\
\text {-lation }\end{array}$ & Unknowns & $\begin{array}{c}\text { CPU } \\
\text { time [h] }\end{array}$ & $\begin{array}{c}\text { Memory } \\
\text { size } \\
\text { [M Byte] }\end{array}$ \\
\hline \multirow{2}{*}{$\operatorname{Mesh}(1)$} & $\mathrm{E}$ & 114,649 & 0.21 & 73.7 \\
\cline { 2 - 5 } & $\mathrm{E}-\phi$ & 134,889 & 0.18 & 88.2 \\
\hline
\end{tabular}

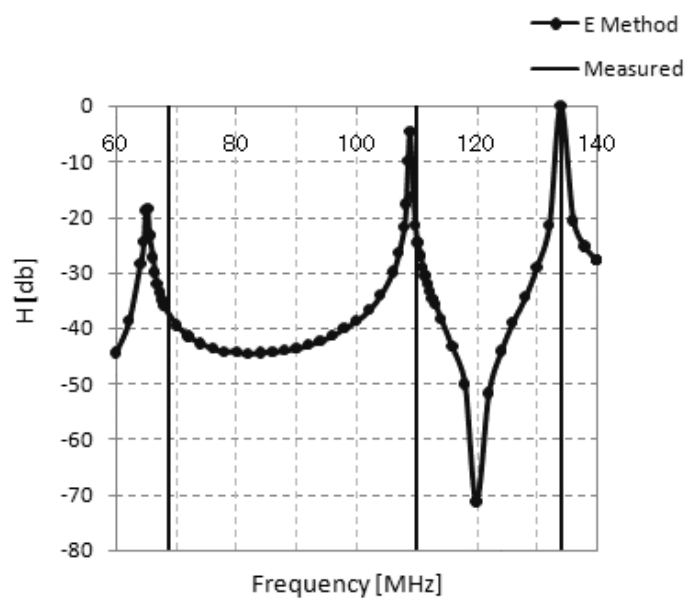

(a) Frequency response by E method

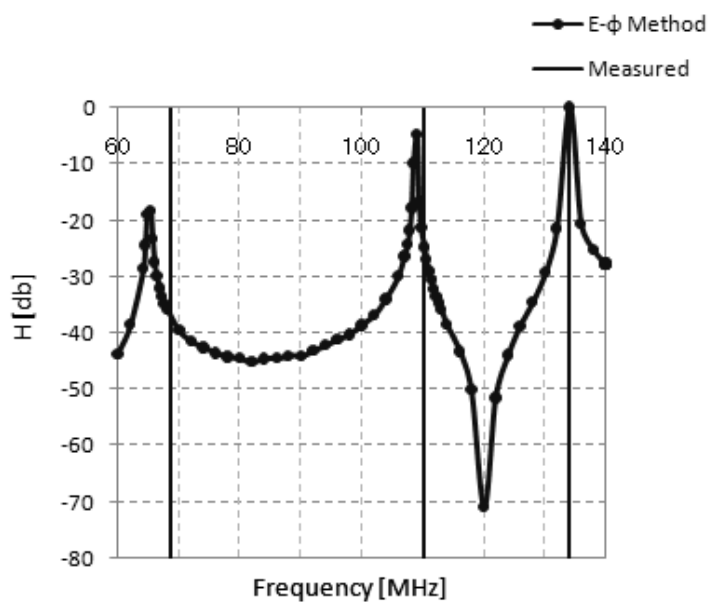

(b) Frequency response by E- $\phi$ method

図 3 周波数応答解析による実測值との比較

Fig. 3. Comparison with measured databy frequency response analyses.

ポテンシャル $\phi$ 導入による計算時間短縮の効果が確認され た。また, E 法と比較して E- $\phi$ 法は計算自由度が一割強増 加するため, 使用メモリサイズも一割強増大するが, 計算 機の合計メモリサイズよりも遥かに小さいため計算上の制 約とならない。

$\mathrm{E}$ 法による磁場の周波数応答を図 3(a), E- $\phi$ 法によるもの を図 3(b)に示す。また, 各 mode での共振周波数に関して計 
表 3 共振周波数の比較 $(\mathrm{MHz})$

Table 3. Comparison of resonant frequencies in $\mathrm{MHz}$.

\begin{tabular}{|c|c|c|c|c|}
\hline $\begin{array}{c}\text { Resonance } \\
\text { mode }\end{array}$ & Measured $^{(15)}$ & $\begin{array}{c}\text { FDTD }^{(15)} \\
25 \mathrm{~mm} \\
\text { mesh }\end{array}$ & $\begin{array}{c}\text { Result } \\
: \mathrm{E}\end{array}$ & $\begin{array}{c}\text { Result } \\
: \mathrm{E}-\phi\end{array}$ \\
\hline 1st & 68.6 & $\begin{array}{c}67 \\
(2.33)\end{array}$ & $\begin{array}{c}65.2 \\
(4.96)\end{array}$ & $\begin{array}{c}65.2 \\
(4.96)\end{array}$ \\
\hline 2nd & 110 & 110 & $\begin{array}{c}109 \\
(0.91)\end{array}$ & $\begin{array}{c}109 \\
(0.91)\end{array}$ \\
\hline 3rd & 134 & 134 & 134 & 134 \\
\hline
\end{tabular}

( ): Error rate between measured data and numerical solutions [\%]

表 4 計算時間および使用メモリサイズ

Table 4. CPU time and memory requirements for each mesh.

\begin{tabular}{|c|c|c|c|c|}
\hline & $\begin{array}{c}\text { Formula } \\
\text {-tion }\end{array}$ & Unknowns & $\begin{array}{c}\text { CPU } \\
\text { time [h] }\end{array}$ & $\begin{array}{c}\text { Memory } \\
\text { size } \\
\text { [M Byte] }\end{array}$ \\
\hline \multirow{2}{*}{$\operatorname{Mesh}(2)$} & $\mathrm{E}$ & $5,355,008$ & 7.43 & 1,860 \\
\cline { 2 - 5 } & $\mathrm{E}-\phi$ & $6,108,799$ & 6.44 & 2,100 \\
\hline \multirow{2}{*}{$\operatorname{Mesh}(3)$} & $\mathrm{E}$ & $11,857,646$ & - & - \\
\cline { 2 - 5 } & $\mathrm{E}-\phi$ & $13,515,847$ & 16.77 & 8,244 \\
\hline
\end{tabular}

算値と実測值および FDTD 法による計算値との比較を表 3 に示す。E 法と E- $\phi$ 法の計算結果は各 mode とも全く同じで あることが確認された。また，実測值と計算值の比較にお いて誤差率の最大が 1st mode で 4.96[\%], 2nd mode で 0.91[\%]，3rd mode で0[\%]であった。各 modeにおける誤差 は高次になるほど減少しているが, FDTD 法による計算值に 含まれる誤差と同様の傾向を示していることがわかる。以 上より, 得られた計算值は十分高い精度を持ち, 手法の妥 当性が確認された。

〈5·3〉大規模解析モデルによる性能検証 ここで は，Mesh(2)，(3)を用いた大規模計算による性能検証につい て述べる。解析周波数を 1 st mode $(65.2 \mathrm{M}[\mathrm{Hz}])$ として, そ の他の計算条件は前項の精度検証の場合と同様である。表 4 に計算時間および使用メモリサイズを示す。また, 図 4 に インターフェース問題における反復計算の残差ノルム収束 履歴を示す。Mesh(2)による計算において，E 法では計算時 間は 7.43[h]であり，E- $\phi$ 法では計算時間は 6.44[h]であった。 これより，前項で述べた Mesh(1)を用いた場合と同様に E$\phi$ 法では，E 法と比較して 1.15 倍高速に計算されているこ とがわかる。また, 収束までに要した反復回数は E 法が 5,865 回, E- $\phi$ 法が 4,685 回であり, スカラーポテンシャル $\phi$ によ って反復回数が約 1,200 回減少していることがわかる。 Mesh(3)による計算においては，E 法は収束に向から傾向は みられるものの, 10,000 回以上反復してもインターフェー 又問題は収束しなかった。一方, E- $\phi$ 法では反復回数が 4,556 回で収束判定条件を満たし計算が完了した。計算に要した 時間は $16.77[\mathrm{~h}]$ であった。これより，大規模計算における E- $\phi$ 法の優位性が確認された。また，使用メモリサイズは， 最も規模が大きい Mesh(3)において 8GB 程度であり, 本検

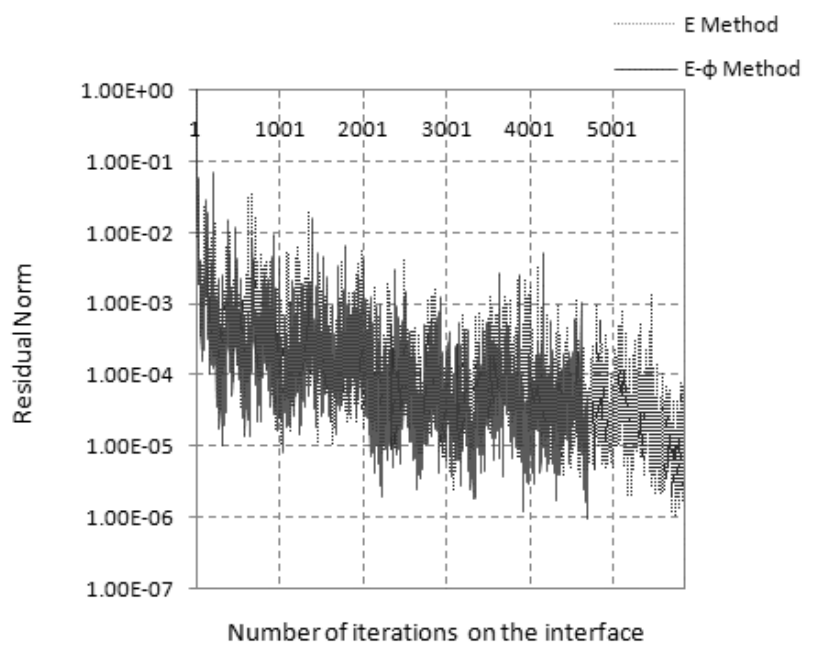

(a) $\operatorname{Mesh}(2)$

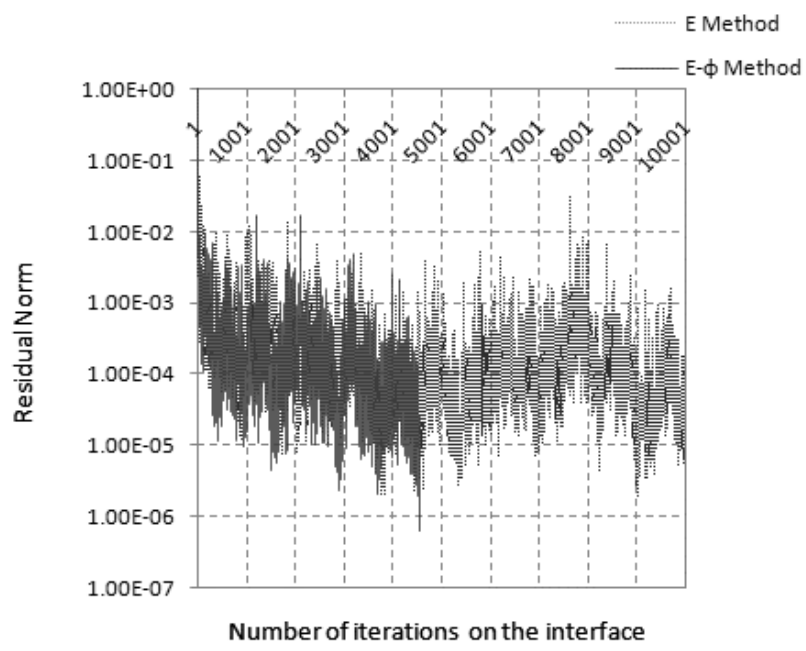

(b) $\operatorname{Mesh}(3)$

図 4 インターフェース問題における反復計算 の残差ノルム

Fig. 4. Residual norm on the interface.

証で用いた計算機環境の合計メモリサイズ (36GB) よりも 小さく, PCクラスタなどの小規模な並列計算機環境におい て十分許容できる範囲内であると考えられる。以上より, 本手法によって，1,000 万複素自由度規模の高周波電磁場問 題を扱うことが可能であることがわかった。

\section{6. まとめ}

本論文において, 階層型領域分割法に基づく高周波電磁 場の大規模有限要素解析手法を提案した。

変位電流を考慮した周波数領域の Maxwell 方程式から導 出される Helmholtz 方程式を解くべき方程式とする有限要 素定式化において, 電場 $\mathrm{E}$ を末知関数とする $\mathrm{E}$ 法による定 式化, 電場 $\mathrm{E}$ およびスカラーポテンシャル $\phi$ を未知関数と する E- $\phi$ 法による定式化についてそれぞれ述べた。並列化 アルゴリズムに関して, COCG 法に基づく反復型領域分割 
法による定式化を示したうえで，階層型領域分割法の適用 手法に関して述べた。

手法の検証として, リエントラント型空洞共振器モデル (TEAM Workshop Problem 29) を用いた周波数応答解析によ る精度検証，および大規模解析モデルによる性能検証を行 い, 有効性を検討した。精度検証の結果, E 法, E- $\phi$ 法によ る計算值はともに実測值および FDTD 法による計算值との 比較において良好な一致を示し, 提案手法によって得られ る解は精度の観点で十分実用的であることを示した。また 性能検証において，600 万および 1,200 万複素自由度規模の 計算を，E法および E- $\phi$ 法によって行った。E法，E- $\phi$ 法と もに 600 万自由度まではインターフェース問題の反復計算 が収束判定条件を満たし計算が完了した。一方， 1,200 万複 素自由度の計算においては, E 法は収束判定条件を満たさず 収束しなかったが, E- $\phi$ 法では収束判定条件を満たし, 計算

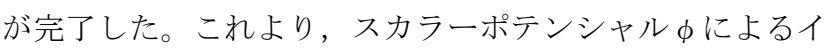
ンターフェース問題の収束特性の改善が確認され, E- $\phi$ 法が 大規模問題において特に有用であることがわかった。今後 は, 電磁環境問題における熱効果の定量評価を目的とした 熱問題との連成解析手法に関して検討を進める。また，イ ンターフェース問題における反復計算の収束特性の更なる 改善のために前処理等ソルバーのアルゴリズムも検討する 予定である。

(平成 20 年 3 月 11 日受付, 平成 20 年 5 月 17 日再受付)

\section{文献}

(1) R. J. Luebbers and H. S. Langdon : "A Simple Feed Model That Reduces Time Step Needed for FDTD Antenna and Microstrip Calculations", IEEE Trans. Antennas Propagate, Vol.44, No.7, pp.1000-1004 (1996)

(2) http://jp.fujitsu.com/solutions/plm/analysis/poynting/

( 3 ) Y. Okamoto, R. Himeno, K. Ushida, A. Ahagon, and K. Fujiwara : "The Coupled Analysis of Electromagnetic Wave and Heat Conduction with Rotational Motion of Heat Target and Temperature-Dependent Complex Permittivity", IEEJ Trans. PE, Vol.127, No.8, pp.902-910 (2007-8) (in Japanese)

岡本吉史・姫野龍太郎・丑田公規・阿波根明・藤原耕二：「非加熱体 の回転運動と温度依存性の複素誘電率を考慮した電磁波・熱伝導連 成解析」, 電学論 B, 127, 8, pp.902-910 (2007-8)

(4) http://www.intel.com/cd/software/products/jikk/jpn/329199.htm

（5）武居 周・吉村 忍・金山 寬: 「並列有限要素法に基づく高周波電 磁場の FULL-WAVE 解析」, 電気学会静止器 - 回転機合同研資, SA-07-65, RM-07-81 (2007)

(6) H. Kanayama, D. Tangami, K. Imoto, and S. Sugimoto : "Finite element computation of magnetic field problems with the displacement current", $J$. Computational \& Applied Mathematics, Vol.159, pp.77-84 (2003)

(7) P. Liu and Y. Q. Jin : "The finite-element method with domain decomposition for electromagnetic bistatic scattering from the comprehensive model of a ship on and a target above a large-scale rough sea surface”, IEEE Trans. Geos., Vol.42, No.5, pp.950-956 (2004)

(8) K. Yosui, T. Iwashita, M. Mori, and E. Kobayashi : "A Parallel Multigrid Solver for High Frequency Electromagnetic Field Analyses with Small-scale PC Cluster", IEEJ Trans. PE, Vol.127, No.8 pp.911-917 (2007-8) (in Japanese)

用水邦明・岩下武史・森 倫也・小林英一: 「小規模 PC クラスタに よる高周波電磁界解析のための並列マルチグリッドソルバ」, 電学論 B, 127, 8, pp.911-917 (2007-8)
（9）矢川元基・塩谷隆二 : 超並列有限要素解析, 計算科学シリーズ, 朝 倉書店 (1998)

(10) A. Toselli and O. Widlund : Domain decomposition methods-Algorithms and theory, Springer Series in Computational Mechanics, Springer (2004)

(11) H. Kanayama, H. Zheng, and S. Sugimoto : "3D Magnetic Field Computations by ADVENTURE_Magnetic", ECCOMAS2004, Vol.2, 580.pdf, pp.1-13 (2004)

(12) S. Yoshimura, R. Shioya, H. Noguchi, and T. Miyamura : "Advanced General-Purpose Computational Mechanics System for Large Scale Analysis and Design", J. Computatational \& Applied Mathematics, Vol.149, pp.279-296 (2002)

(13) R. Shioya, H. Kanayama, A. M. M. Mukaddes, and M. Ogino : "Heat conductive analysis with balancing domain decomposition method", $J$. Theoretical \& Appl. Mechanics, Vol.52, pp.43-53 (2003)

(14) H. Kanayama and S. Sugimoto : "Effectiveness of A- $\phi$ method in a parallel computing with an iterative domain decomposition method", IEEE Trans. Mags., Vol.42, No.4, pp.539-542 (2006)

(15) Y. Kanai : "Description of TEAM Workshop Problem 29 : Whole body cavity resonator", TEAM Workshop in Tucson (1998)

(16) http://日本総研.jp/pro-eng/jmag/analysis/resunant-freq_wv/index.html

(17) A. Takei, S. Yoshimura, and H. Kanayama : "Large scale finite element analyses of high frequency electromagnetic field in commuter trains", Proc. of APCOM'07/EPMESC XI, CD-ROM/MS43-1-2 (2007)

(18) 電気学会編: 計算電磁気学, 培風館 (2003)

（19）金山 寛：計算電磁気学, 岩波講座「現代工学の基礎」, 岩波書店 (2000)

（20）武居 周・吉村 忍・金山 寛:「階層型領域分割法による大規模高 周波電磁場解析」, 電気学会マグネティックス・静止器・回転機合同 研資, MAG-08-21, SA-08-9, RM-08-9 (2008)

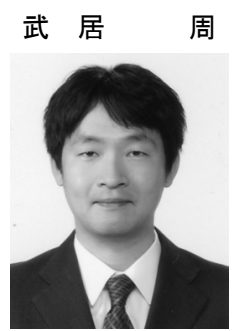

（正員） 1973 年 10 月 25 日生。1997 年 3 月法 政大学工学部卒業。1999 年 3 月法政大学大学院 修士課程修了。同年 4 月富士通 (株) 入社。 2006 年 3 月東京大学大学院新領域創成科学研究科博 士課程修了。同年 4 月東京大学大学院工学系研 究科システム量子工学専攻博士研究員。法政大 学デザイン工学部兼任講師。現在, 主として大 規模電磁場解析に関寸る研究に従事。東京大学 博士 (環境学)。日本計算工学会, 日本シミュレーション学会会員。

吉 村 忍 (非会員) 1959 年 3 月 18 日生。1 981 年 3 月東

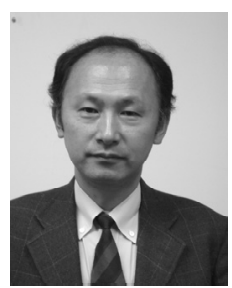
京大学工学部卒業。1987 年 3 月東京大学大学院 博士課程修了。工学博士。同大学講師, 助教授, 人工物工学研究センター助教授, システム量子 工学専攻助教授, 新領域創成科学研究科環境学 専攻教授, 工学系研究科システム量子工学専攻 教授を経て, 2008 年より同システム創成学専攻 教授。知的シミュレーションの開発と環境分 野, 工学分野への応用に関寸る研究・教育に従事。日本計算力学連 合副会長, 日本計算工学会評議員, 日本機械学会フェロー。日本シ ミュレーション学会, 日本応用数理学会会員。

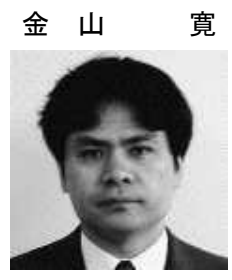

(正員) 1949 年 3 月 19 日生。1971 年 3 月京 都大学卒業。1 1972 年 4 月富士電機（株）入社。 1988 年東京大学工学博士。1997 年 4 月九州大 学工学部教授。現在, 同大学院工学研究院教授。 International Compumag Society, 日本機械学会, 日本応用数理学会, 日本計算工学会, 日本シミ ュレーション学会会員。 